\title{
Studies on a novel series of acyl ester prodrugs of prostaglandin $\mathrm{F}_{2 \alpha}$
}

\author{
A Cheng-Bennett, M F Chan, G Chen, T Gac, M E Garst, C Gluchowski, L J Kaplan, \\ C E Protzman, M B Roof, G Sachs, L A Wheeler, L S Williams, D F Woodward
}

\begin{abstract}
A novel series of prostaglandin $\mathbf{F}_{2 u}\left(\mathbf{P G F}_{2 u}\right)$ prodrugs, with acyl ester groups at the 9, 11, and 15 positions, was prepared in order to design clinically acceptable prostaglandins for treating glaucoma. Studies involving isolated esterases and ocular tissue homogenates indicated that 9-acyl esters cannot provide a prodrug since $\mathbf{P G F}_{2 u}$ would not be formed as a product. In contrast, 11-mono, 15-mono, and 11, 15-diesters were converted to $\mathbf{P G F}_{2 \alpha}$ in ocular tissues and could, therefore, be considered as prodrugs of $\mathbf{P G F}_{2 u}$. Carboxylesterase (CE) appeared critically important for the hydrolytic conversion of those $\mathrm{PGF}_{2 u}$ prodrugs where the 11 or 15-OH group was esterfied and such prodrugs were not substrates for acetylcholinesterase (ACHE) or butyrylcholinesterase (BuCHE). The enzymatic hydrolysis of $\mathrm{PGF}_{2 u}-1$-isopropyl ester was also investigated for comparative purposes. This PGF $_{2 u}$ prodrug was a good substrate for $\mathrm{CE}$, but was also hydrolysed by BuCHE, albeit at a much slower rate. The most striking feature of the enzymatic hydrolysis of $\mathbf{P G F}_{2 u}$-1-isopropyl ester in ocular tissue homogenates was that it was much faster than for prodrugs esterified at the 11 and/or 15 positions. In terms of ocular hypotensive activity, all prodrugs which showed detectable conversion to nascent PGF $_{2 u}$ were potent ocular hypotensives. Although no separation of ocular hypotensive and ocular surface hyperaemic effects was apparent for PGF $_{2 u}$-1-isopropyl ester, a temporal separation of these effects was apparent for

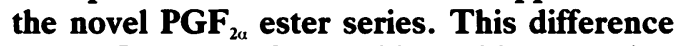
may reflect an unfavourably rapid conversion of $\mathrm{PGF}_{2 u^{-1}}$-isopropyl ester in ocular surface tissues compared with anterior segment tissues.

(Brf Ophthalmol 1994; 78: 560-567)
\end{abstract}

Allergan, Inc, Biological Sciences and Medicinal Chemistry, Irvine, California, USA A Cheng-Bennett

M F Chan

G Chen

T Gac

M E Garst

C Gluchowski

L J Kaplan

C E Protzman

$M$ B Roof

G Sachs

L A Wheeler

L S Williams

D F Woodward

Correspondence to:

Dr D F Woodward

Department of Biological

Department of Biological

Sciences, Allergan, Inc, 2525
Dupont Drive, PO Box 19534

Dupont Drive, PO Box 19534,
Irvine, CA 92713-9534, USA.

Accepted for publication

15 March 1994 physiological $\mathrm{pH}$, is transformed by esterification to a non-polar, highly lipophilic species. This greatly enhances corneal uptake which ultimately results in improved delivery of nascent $\mathrm{PGF}_{2 u}$ to anterior segment tissues. ${ }^{10}$ Despite the fact that esterifying the carboxylic acid group of $\mathrm{PGF}_{2 u}$ improves bioavailability, it does not appear to result in a clinically acceptable ophthalmic drug because of ocular surface side effects. When considering the design of $\mathrm{PGF}_{2 \mathrm{a}}$ prodrugs, there are alternatives to esterifying the carboxylic acid. ${ }^{112} \mathrm{PGF}_{2 u}$ contains three $-\mathrm{OH}$ groups at positions 9,11 , and 15 which provide other options for synthesising ester prodrugs of $\mathrm{PGF}_{2 \mathrm{u}}$.

In order to investigate alternative opportunities for the design of $\mathrm{PGF}_{2 \mu}$ prodrugs with potential ophthalmic application, a novel series of $\mathrm{PGF}_{2 \mathrm{a}}$ alkyl acyl esters was synthesised which comprised 9, 11, and 15 monoesters; and 9, 11, 9, 15 , and 11,15 diesters. Three PGF $_{2 \alpha}$ lactones were also examined where the carboxylic acid moiety forms an internal ester with one of the $-\mathrm{OH}$ groups. In order to characterise these $\mathrm{PGF}_{2 \mathrm{a}}$ esters the following factors received particular attention: (1) inherent pharmacological activity, (2) ester hydrolysis by esterases and ocular tissues, (3) effects on intraocular pressure, and (4) ocular surface hyperaemia.

\section{Materials and methods}

\section{PHARMACOLOGICAL ACTIVITY}

Inherent pharmacological activity was assessed in an FP receptor preparation. ${ }^{13}$ Mouse Swiss 3T3 fibroblasts were plated in culture flasks and were fed Dulbecco's modified Eagle's medium (DMEM) containing $10 \%$ fetal calf serum, $2 \mathrm{mM}$ L-glutamine, and $0.05 \mathrm{mg} / \mathrm{ml}$ gentamicin (all purchased from Gibco, Grand Island, NY, USA). Cell cultures were maintained in a humidified atmosphere of $95 \%$ air, $5 \%$ carbon dioxide and grown to confluency.

Cells were removed from the culture flasks by a 1 minute treatment with trypsin $0.05 \% / 0.52$ mM EDTA (Gibco, Grand Island, NY, USA) at $37^{\circ} \mathrm{C}$. Proteolytic activity was arrested by adding $5 \mathrm{ml}$ of $10 \%$ fetal bovine serum in DMEM. The cells were consecutively washed in Hank's balanced salt solution and Maullem's buffer ${ }^{14}$ : centrifugation for the washes was performed for 15 minutes at $1200 \mathrm{rpm}$ at room temperature. Cells were counted, resuspended in Maullem's buffer and incubated with $2 \mu \mathrm{M}$ Fura 2/acetoxymethyl ester in a shaking water bath for 30 minutes at $37^{\circ} \mathrm{C}$. The cells were subsequently washed in Maullem's buffer as above and resuspended at a concentration of $2 \times 10^{6}$ cells $/ \mathrm{ml}$. Aliquots of $0.5 \mathrm{ml}$ cell suspension were then added to autocap microtubes to provide $10^{6}$ cells per experimental determination of $\left[\mathrm{Ca}^{2+}\right]$.

Fluorescence was measured in a Perkin-Elmer 
LS-5 fluorescence spectrophotometer at excitation and emission wavelengths of 340 and 492 $\mathrm{nm}$, respectively with both slits at $10 \mathrm{~nm}$. For each experimental determination $10^{6}$ cells were washed in Maullem's buffer at $1200 \mathrm{rpm}$ for 5 minutes, suspended in a $3 \mathrm{ml}$ cuvette containing $10^{-6} \mathrm{M}$ eserine (Sigma, St Louis, MO, USA) and dissolved in Maullem's buffer. Stirring was achieved by an overhead mounted paddle stirrer with the temperature maintained at $37^{\circ} \mathrm{C}$. Calibration of the Fura 2 signal was as previously described for UMR-106 cells. ${ }^{14}$ Stock solutions of $\mathrm{PGF}_{2 \mu}$ and the prodrugs were prepared in $0 \cdot 1 \%$ polysorbate $80 / 10 \mathrm{mM}$ TRIS.

\section{ESTER HYDROLYSIS}

Acetylcholinesterase (ACHE) extracted from electric eel, butyrylcholinesterase (BuCHE) extracted from horse serum, and carboxylesterase (CE) extracted from porcine liver were purchased from Sigma (St Louis, MO, USA). Ocular tissues were obtained from New Zealand white rabbits (2-3 kg) and were used fresh for metabolic studies. The corneal epithelium was removed by gentle scraping with a scalpel, the corneal stroma endothelium, the bulbar conjunctiva, and the iris-ciliary body were then surgically excised. Excised tissues were kept on ice, cut into small pieces and homogenised with a VirTishear homogeniser (The VirTis Co Inc, Gardiner, NY, USA) in ice cold $0 \cdot 1 \mathrm{M}$ phosphate buffered saline at $\mathrm{pH} 7 \cdot 4$. The homogenate was centrifuged at $3000 \mathrm{rpm}$ for 30 minutes in a Beckman J221 centrifuge (Beckman Instruments, Fullerton, CA, USA) at $4^{\circ} \mathrm{C}$. The supernatant was collected and stored at $-70^{\circ} \mathrm{C}$ until use. Protein contents were determined by BioRad assay (BioRad, Richmond, CA, USA) using bovine serum albumin as a standard.

PGF $_{2 a}$ prodrug metabolism was determined by incubating [10 $\mu \mathrm{M}]$ with esterase or ocular tissue homogenate in $0 \cdot 1 \mathrm{M}$ phosphate buffer at $\mathrm{pH} 7 \cdot 4$ and $37^{\circ} \mathrm{C}$, with shaking at 100 oscillations/min in air. Aliquots $(300 \mu \mathrm{l})$ of the incubation mixture were sampled at predetermined times throughout the experimental period and treated with $200 \mu \mathrm{l}$ of $0.3 \mathrm{~N}$ perchloric acid. Extraction was performed with $5 \mathrm{ml}$ of dichloromethane. Four $\mathrm{ml}$ of the organic extract were removed and evaporated under a stream of nitrogen. The residue was reconstituted in organic solvent, injected, and analysed with high performance liquid chromatography for concentrations of parent prodrug, intermediate and/or $\mathrm{PGF}_{2 \mathrm{u}}$. Three chromatographic systems were used for the analyses of the diesters, monoesters, and $\mathrm{PGF}_{2 \mathrm{u}}$. These consisted of a Beckman 114 pump (Beckman Instruments, Fullerton, CA, USA), a Kratos 783 detector (Kratos Analytical, Ramsey, NJ, USA), and a Waters 710 WISP autoinjector (Millipore, Milford, MA, USA). The mobile phase consisted of a mixture of $0.02 \mathrm{M} \mathrm{KH}_{2} \mathrm{PO}_{4}$ (pH adjusted to 3.0 with $\left(\mathrm{H}_{3} \mathrm{PO}_{4}\right)$ and acetonitrile. The flow rates were $1.5 \mathrm{ml} / \mathrm{min}$. Waters Novopack ODS columns $(3.9 \mathrm{~mm} \times 150 \mathrm{~mm}$, $4 \mu \mathrm{m})$ were employed and effluents were monitored using $200 \mathrm{~nm}$ detection. The output from the ultraviolet detector was interfaced with the Nelson chromatographic data collection system (Perkin Elmer Nelson System, Inc, Cupertino, CA, USA). Rate constants for ester hydrolysis were derived from the slope of the ln concentration-time plot. All metabolism experiments were performed in quadruplicate and the rate constant is finally expressed as the mean (SEM) of the four individually determined rate constants. They are normalised for ocular tissue homogenate protein concentration $(\mathrm{h} / \mathrm{mg}$ protein).

\section{IN VIVO EXPERIMENTS}

Intraocular pressure studies were performed in rabbits since this species mimics the response of human eyes to $\mathrm{PGF}_{2 u}$ in that $\mathrm{PGF}_{2 u}$ produces pronounced ocular surface hyperaemia. New Zealand albino/Dutch belted crossbred rabbits of both sexes and weighing $1 \cdot 5-2 \cdot 5 \mathrm{~kg}$ were used. These rabbits had not previously received any topical drugs. Intraocular pressure was measured with a pneumatonometer (Digilab) calibrated against the eyes of anaesthetised rabbits by closed stopcock manometry. The correlation coefficient over a $10-30 \mathrm{~mm} \mathrm{Hg}$ range was 0.98 . The animals were acclimatised to pneumatonometry by taking unrecorded measurements before experimental determinations of intraocular pressure. Corneal anaesthesia for tonometry was provided by topical application of one drop of $0.05 \%$ proxymetacaine (proparacaine, Allergan).${ }^{4}$ Intraocular pressure data were tabulated as the difference between the change from baseline in intraocular pressure in test and control eyes as a convenience for depicting the large body of data. Statistical analysis employed Student's paired $t$ tests. Ocular surface hyperaemia was assessed visually in rabbits and is described as either present to any extent or completely absent.

All topical formulations were prepared in $0 \cdot 1 \%$ polysorbate $80 / 10 \mathrm{mM}$ TRIS and administered in a $25 \mu \mathrm{l}$ volume: the contralateral eye received $25 \mu \mathrm{l}$ vehicle as a control. Prostaglandin $F_{2 u} 1,9,1,11$, and 1,15 lactones were a generous gift from Upjohn (Kalamazoo, MI, USA), all other $\mathrm{PGF}_{2 u}$ esters were synthesised in house. ${ }^{11} 1215-19$

Animal care and experimentation were performed according to the ARVO resolution on the use of animals in research.

\section{Results}

INTRACELLULAR [ $\left.\mathrm{Ca}^{2+}\right]$ EFFECTS

The effect of the $\mathrm{PGF}_{2 \mathrm{u}}$ esters on the intracellular $\left[\mathrm{Ca}^{2+}\right]$ in Swiss 3T3 cells was used as an indicator of inherent pharmacological activity and results are depicted in Figures 1-4. Standards for comparison are provided in Figure 1 where PGF $_{2 \text {. }}$ produces a dose dependent increase in intracellular $\left[\mathrm{Ca}^{2+}\right]$ which reaches maximum at $10^{-6} \mathrm{M}$ (Fig 1A) while PGF $_{24}$-1-isopropyl ester does not even produce a modest threshold effect until a $10^{-5} \mathrm{M}$ concentration is reached (Fig $1 \mathrm{~B}$ ). Sample recordings for these two compounds are provided in Figure 2. The effect of 9, 11, and 15 monoesters is depicted in Figure 3. By comparing dose-response curves it is apparent that $\mathrm{PGF}_{2 \mathrm{u}}-9$-acetate retained a considerable degree of 
Figure 1 Comparison of the effects of $(A) P G F_{2 a}$ and (B) $P G F_{2 u}-1$-isopropyl ester on intracellular $\left[\mathrm{Ca}^{2+}\right]$ in Swiss $3 T 3$ cells. Values are mean $(S E M) n=4$.
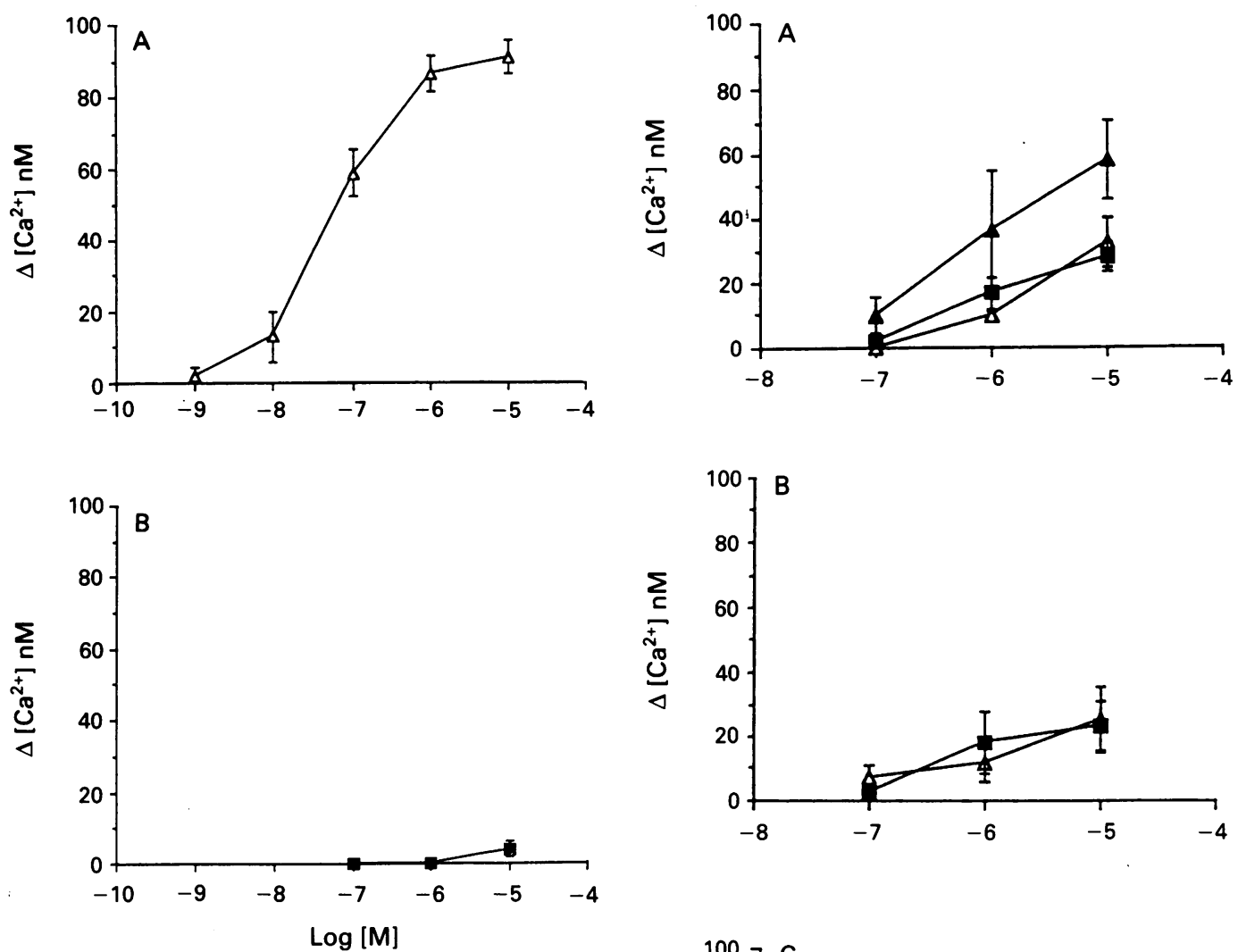

inherent pharmacological activity and was only tenfold less potent than PGF $_{2 u}$ (Fig 3A). In contrast, larger ester substituents at position 9 resulted in less active compounds which produced a clear threshold response only at $10^{-6} \mathrm{M}$ (Fig 3A).

Similarly, ester substituents, such as isobutyryl, isovaleryl, and pivaloyl at position 11 or 15 resulted in compounds with inherent pharmacological activity similar to that of their 9-monoester equivalents (Fig 3B, 3C). Diesterification of $\mathrm{PGF}_{2 \alpha} \mathrm{OH}$ groups resulted in a decrease in inherent pharmacological activity (Fig 4) such that they resembled $\mathrm{PGF}_{2 u}-1$ isopropyl ester in this regard. Thus, for 9,11 (Fig 4A), 9, 15 (Fig 4B), and 11, 15 (Fig 4C) diesters, no alteration in intracellular $\left[\mathrm{Ca}^{2+}\right]$ was observed until a $10^{-5} \mathrm{M}$ concentration was achieved. The $1,9,1,11$, and 1,15 lactones and PGF $_{2 u}-1$ isopropyl, 11-pivaloyl diester exhibited no changes in intracellular $\left[\mathrm{Ca}^{2+}\right]$ up to $10^{-5} \mathrm{M}$ (data not shown).

\section{PGF $_{2 \alpha}$ ESTER HYDROLYSIS}

Figure 5 depicts two typical concentration-time profiles which illustrate the disappearance of parent prodrug and the formation of product,

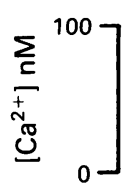

Figure 2 Sample recordings of the $\mathrm{Ca}^{2+}$ signal in response to $(A) P G F_{2}$ $10^{-5} M(B) P G F_{2 a}^{-}$ 1-isopropyl ester $10^{-5} \mathrm{M}$.

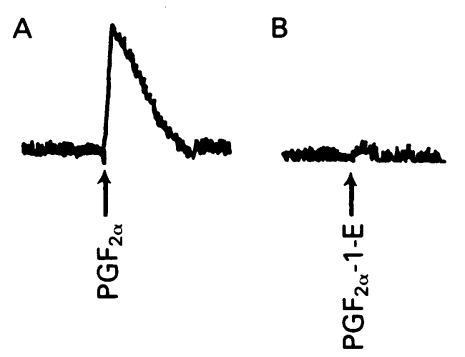

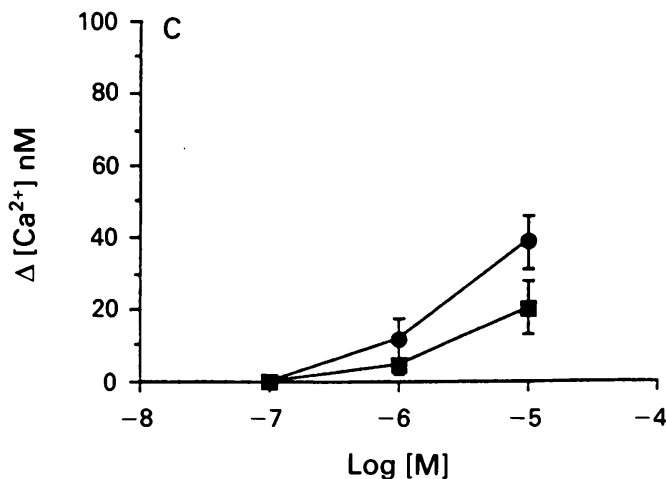

Figure 3 Comparison of the effects of $P G F_{2 u}$-monoesters on intracellular $\left[\mathrm{Ca}^{2+}\right.$ in Swiss $3 \mathrm{~T} 3$ cells. The effects of $P G F_{2 a}$-9-acetate $(\triangle), P G F_{2 n}-9$-isobutyrate $(\triangle)$, and $P G F_{2 \mathrm{a}}-9$-pivalate $(\square)$ are shown in $(A)$. $(B)$ depicts the effects of $P G F_{2 \mathrm{a}}-11$-isobutyrate $(\triangle)$ and $P G F_{2 \mathrm{a}}-11$ pivalate. (C) depicts the effects of $P G F_{21}-15$-isovalerate (O), and $P G F_{2 \mathrm{a}}-15$-pivalate (ם). Values are mean (SEM); $n=3-4$.

with determination of mass balance. The conversion of PGF $_{2 u}$-1-isopropyl ester to PGF $_{2 u}$ (Fig 5A) and the conversion of $\mathrm{PGF}_{2 \mu}$ 9, 11-dipivaloyl ester to $\mathrm{PGF}_{2 \mathrm{u}}-9$-pivaloyl ester (Fig 5B) are used to provide typical examples.

Table 1 compares the rate constants for the hydrolysis of the monopivaloyl esters and PGF $_{2 \mathrm{u}}$-1-isopropyl ester to $\mathrm{PGF}_{2 \mathrm{u}}$ in rabbit ocular tissue homogenates. No detectable hydrolysis of PGF $_{2 \mathrm{u}}$-9-pivaloyl ester was apparent. $\mathrm{PGF}_{2 \mathrm{u}}-11$ pivaloyl ester was hydrolysed at a slow rate in all tissues whereas $\mathrm{PGF}_{2 \mathrm{u}}-15$-pivaloyl ester was hydrolysed approximately one order of magnitude faster. The most striking feature was the rapid hydrolysis of $\mathrm{PGF}_{2 \mathrm{u}}$-1-isopropyl ester in the corneal epithelium. However, in the iris-ciliary body and conjunctiva the hydrolysis rate for PGF $_{2 u}$-15-pivaloyl ester exceeded that for PGF $_{2 \mathrm{u}}$-1-isopropyl ester by approximately threefold.

The enzymatic hydrolysis pathways for con- 
Figure 4 Comparison of the effects of $P G F_{2 u}$-diesters on intracellular $\left[\mathrm{Ca}^{2+}\right]$ in

Swiss $3 T 3$ cells. The effects of $P G F_{2 u}-9,11$-diacetate

(A), $P G F_{2 u}-9,11$

diisovalerate (O), and

PGF $_{2 \text { 9,11-dipivalate ( }}$ are shown in $(A) .(B)$

Depicts the effects of

$P G F_{2 u}-9$-15-diisobutyrate

( $\triangle), P G F_{24}-9,15-$

diisovalerate (O), and

$P G F,-9,15$-dipivalate

(G). $(C)$ depicts the effects of $P G F_{2 \mathrm{u}}-11,15$ -

diisobutyrate $(\triangle)$

$P G F_{2 u}-11,15$-diisovalerate

(O), and $P G F_{24}-11,15-$

dipivalate $(\boldsymbol{\square})$. Values are mean $(S E M) ; n=3-4$.
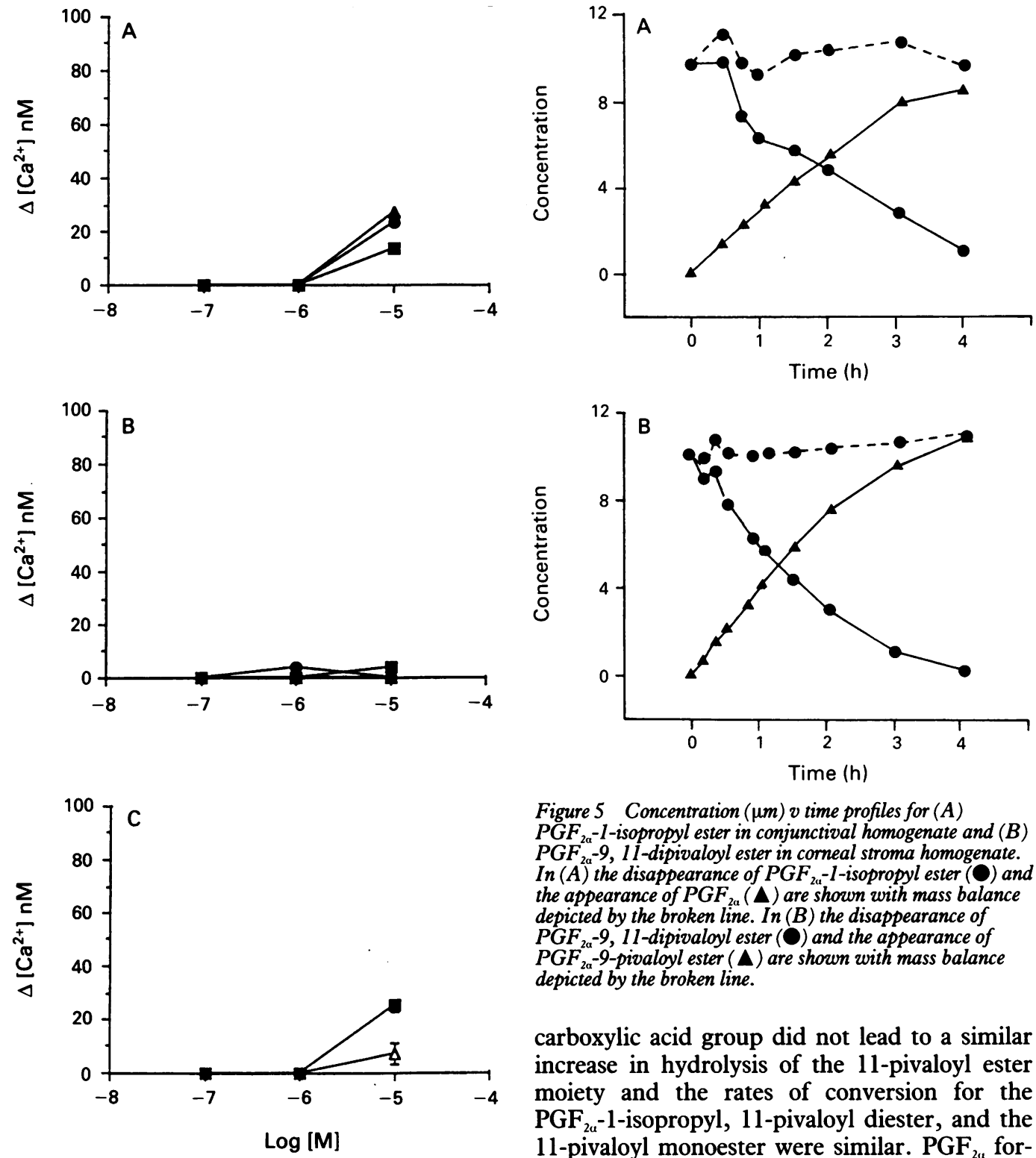

version of representative diesters in ocular tissue homogenates are depicted in Figures 6 and 7. Detectable levels of PGF $_{2 u}$ were not observed for the 9, 11 and 9, 15-dipivaloyl esters and values describe the rate constants for conversion to the 9-monoester (Table 2A). Enzymatic hydrolysis of $\mathrm{PGF}_{2 \mathrm{a}}-11$, 15-dipivaloyl ester was found to be complex and formation of PGF $_{2 u}$ occurred exclusively via the 15 -monoester intermediate (Fig 7). Hydrolysis of the 11-pivaloyl group was, therefore, much faster than for the 15-pivaloyl ester, which is in distinct contrast with the hydrolysis rates for monopivalates (Table 1 ).

Indeed, the 15-pivaloyl ester was the only detectable intermediate in ocular tissues, except for a very small quantity of the 11-pivaloyl ester in the iris-ciliary body. In contrast with the irisciliary body, corneal endothelium and corneal epithelium, $\mathrm{PGF}_{2 u}$ formation from $\mathrm{PGF}_{2 u}, 15-$ pivalate was very rapid in the conjunctiva preventing accurate measurement of $K_{2}$ over the experimental period. It is also of interest to note that although conversion of the 11-pivaloyl monoester to $\mathrm{PGF}_{2 u}$ was slow in all tissues, the presence of an additional ester substituent in either the 9 or 15 position increased the rate of hydrolysis at the 11-position. Esterification of the
Figure 5 Concentration $(\mu m) v$ time profiles for $(A)$ $P G F_{2 \alpha}-1$-isopropyl ester in conjunctival homogenate and $(B)$ $P G F^{2 \alpha}-9,11$-dipivaloyl ester in corneal stroma homogenate. In $(A)$ the disappearance of $P G F_{2 a}-1$-isopropyl ester $(O)$ and the appearance of $P G F_{2 a}(\Delta)$ are shown with mass balance depicted by the broken line. In $(B)$ the disappearance of $P G F_{2 a}-9,11-$ dipivaloyl ester (O) and the appearance of $P G F_{20}-9$-pivaloyl ester $(\Delta)$ are shown with mass balance depicted by the broken line.

carboxylic acid group did not lead to a similar increase in hydrolysis of the 11-pivaloyl ester moiety and the rates of conversion for the $\mathrm{PGF}_{2 \mathrm{u}}$-1-isopropyl, 11-pivaloyl diester, and the 11-pivaloyl monoester were similar. $\mathrm{PGF}_{2 \alpha}$ formation from $\mathrm{PGF}_{2 u}$ 1, 11-lactone proceeded at a yet slower rate. The rates of $\mathrm{PGF}_{2 \mathrm{u}}$ formation per se are reported in Table 3.

Rate constants for the hydrolysis of selected PGF $_{2 u}$ esters by isolated esterases are given in Table 4. None of the $\mathrm{PGF}_{2 u}$ esters studied were substrates for ACHE and only PGF $_{2 u}$-1-isopropyl ester was hydrolysed by BuCHE, albeit at a much slower rate than by CE. Pivaloyl ester groups at positions 11 and 15 were also hydrolysed by $C E$. In contrast, $\mathrm{CE}$ did not hydrolyse pivaloyl ester groups at position 9 as indicated by an inability to metabolise the 9-pivaloyl monoester or the 9-monoester product of the 9, 11 and 9, 15dipivaloyl diesters.

\section{INTRAOCULAR PRESSURE/OCULAR SURFACE} HYPERAEMIA

The effects of $\mathrm{PGF}_{2 u}, \mathrm{PGF}_{2 \mathrm{u}}$-1-isopropyl ester, the 9,11 , and 15-monoesters, and the diesters on rabbit intraocular pressure are summarised in Table 5. Ocular surface hyperaemia is described as the percentage of animals which exhibited observable redness of the eyelid or the bulbar conjunctiva/sclera. $\mathbf{P G F}_{2 u}$ and $\mathbf{P G F}_{2 u}$-1-isopropyl ester both lowered intraocular pressure, but significant decreases were almost invariably 
Table 1 Rate constants (/h/mg protein) (SD) for the hydrolysis of monoesters to $P G F_{24}$ in the presence of rabbit ocular tissue homogenates

\begin{tabular}{|c|c|c|c|c|}
\hline & Corneal epithelium & Corneal stroma & Iris-ciliary body & Conjunctiva \\
\hline $\begin{array}{l}\text { 1-isopropyl } \\
\text { 9-pivalate }\end{array}$ & $38(4 \cdot 2)$ & $\underset{\star}{2 \cdot 0}(0 \cdot 13)$ & $12(6 \cdot 4)$ & ${ }_{\star}^{4.7}(0 \cdot 19)$ \\
\hline $\begin{array}{l}\text { 11-pivalate } \\
\text { 15-pivalate }\end{array}$ & $\begin{array}{l}0.22(0.01) \\
4.4(0.06)\end{array}$ & $\begin{array}{l}0.22(0.01) \\
2 \cdot 1(0.12)\end{array}$ & $\begin{array}{c}1 \cdot 1(0 \cdot 04) \\
33(5 \cdot 7)\end{array}$ & $\begin{array}{l}0.31(0.03) \\
12(2.5)\end{array}$ \\
\hline
\end{tabular}

^ No detectable hydrolysis.

Figure 6 Enzymatic hydrolysis $\left(\mathrm{E}-\mathrm{H}_{2} \mathrm{O}\right)$

pathway for $P G F_{2 a} 9,11$ dipivaloyl ester (compound 1) and $P G F_{2 a} 9,15$ dipivaloyl ester (compound 2) to PGF 9 9-monopivaloyl ester (compound 3) +

pivalic acid (in parenthesis). No conversion of $P G F_{2 a}$ 9-monopivaloyl ester to nascent $P G F_{2 a}$ was detected. associated with a total incidence of ocular surface hyperaemia, which did not resolve until the ocular hypotensive effects were either minimal or absent. PGF $2{ }_{2 u}$-9-isobutyryl and PGF $_{2 u}$-9-pivaloyl esters both produced decreases in intraocular pressure with a similar potency to $\mathrm{PGF}_{2 \alpha}$, but with a reduced incidence of ocular surface hyperaemia at $0 \cdot 1 \%$. At $1 \%$ doses the 9 -monoesters also produced the initial ocular hypertensive response typically produced by $\mathrm{PGF}_{2 u}$ and $\mathrm{PGF}_{2 u}$-1-isopropyl ester. $\mathrm{PGF}_{2 u} 11$ and 15monoesters potently lowered intraocular pressure and exhibited some separation of ocular hypotensive and ocular surface hyperaemic effects at later time points. The 11-pivaloyl and 15-pivaloyl esters were approximately equipotent to $\mathrm{PGF}_{2 u}$-1-isopropyl ester. The activity of the diesters examined was highly dependent on the position of the ester groups. Diesters with a functionality at position 9 did not profoundly lower intraocular pressure and generally exhibited a rather shallow dose-response profile. In contrast, the 11, 15-diesters produced clear dose dependent changes in intraocular pressure. All diesters exhibited a similar level of separation<smiles>CCCCCCC=CC[C@@H]1[C@@H](/C=C/[C@H](O)CCCCC(=O)O)[C@@H](OC(=O)C(C)(C)C)C[C@@H]1CC(=O)O</smiles><smiles>CCCCCCC=CC[C@H]1[C@@H](OC(=O)C(C)(C)C)C[C@@H](O)[C@@H]1C=C[C@@H](CCCCCC(=O)O)OC(=O)C(C)(C)C</smiles>

Figure 7 Enzymatic hydrolysis $\left(\mathrm{E}-\mathrm{H}_{2} \mathrm{O}\right)$ pathway for $P G F_{2 \mathrm{a}} 11,15$ dipivaloyl ester (compound 1). The major pathway is via the PGF 15 monopivaloyl ester intermediate (compound 2) to $P G F_{2 a}$ (compound 4) with pivalic acid liberated at each conversion step (in parentheses). The rate constants for this two step process, $K$ and $K$ are given in Table $2 B$. An alternative enzymatic hydrolysis pathway to $P G F_{2 a}$ 11-monopivaloyl ester (compound 3) is indicated by the broken arrow. This pathway was, however, absent in ocular tissues except for the irisciliary body where it represented only a minor component. $P G F_{21} 11-$ monopivaloyl ester is then converted to $P G F_{2 u}$.

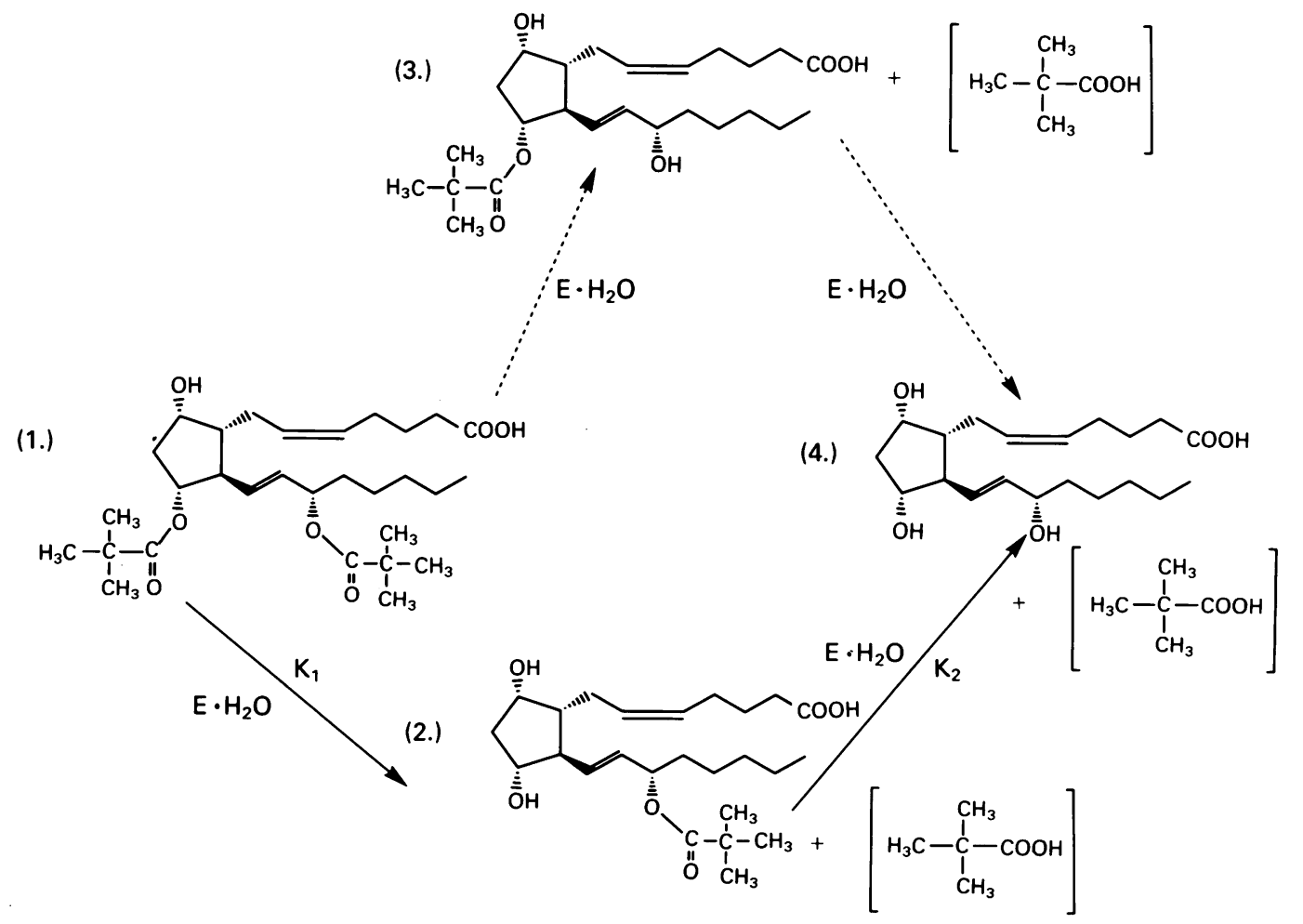


Table 2 A Rate constants (/h/mg protein) (SD) for the hydrolysis of 9,11 and $9,15-$ dipivaloyl esters of $P G F_{2 \pi}$ in the presence of rabbit ocular tissue homogenates. Note PGF 9-pivaloyl ester is the only product

\begin{tabular}{lllll}
\hline & Corneal epithelium & Corneal stroma & Iris-ciliary body & Conjunctiva \\
\hline 9, 11-dipivaloyl ester & $6 \cdot 4(0.79)$ & $1 \cdot 9(0 \cdot 20)$ & $70(6 \cdot 6)$ & $23(0 \cdot 80)$ \\
9, 15-dipivaloyl ester & $5 \cdot 1(0.87)$ & $1 \cdot 3(0 \cdot 01)$ & $30(4 \cdot 5)$ & $11(0.59)$ \\
\hline
\end{tabular}

$B$ Rate constants (/h/mg protein) $(S D)$ for the hydrolysis of $P G F_{2 a} 11,15$-dipivalate ester in the presence of rabbit ocular tissue homogenates

\begin{tabular}{lllll}
\hline & Corneal epithelium & Corneal stroma & Iris-ciliary body & Conjunctiva \\
\hline $\mathrm{K}_{1}$ & $2 \cdot 4(0.1)$ & $0.61(0.03)$ & $3.2(0 \cdot 28)$ & $1.5(0.05)$ \\
$\mathrm{K}_{2}$ & $2 \cdot 5(0.1)$ & $0.70(0.04)$ & $14(1.6)$ & - \\
\hline
\end{tabular}

Table 3 Rate (nmol/h/mg protein) of $P G F_{2 \alpha}$ formation for $P G F_{2 \alpha}$ prodrugs

\begin{tabular}{|c|c|c|c|c|}
\hline & Corneal epithelium & Corneal stroma & Iris-ciliary body & Conjunctiva \\
\hline $\begin{array}{l}\text { 1-isopropyl } \\
\text { 1-isopropyl, 11-piv }\end{array}$ & $\begin{array}{l}230(23) \\
4 \cdot 0(0 \cdot 17)\end{array}$ & $\begin{array}{l}15(0 \cdot 56) \\
3.0(0 \cdot 14)\end{array}$ & $\begin{array}{l}81(2 \cdot 7) \\
5 \cdot 3(0 \cdot 23)\end{array}$ & $\begin{array}{l}33(0.68) \\
1.5(0 \cdot 20)\end{array}$ \\
\hline $\begin{array}{l}\text { 9-pivalate } \\
\text { 11-pivalate } \\
\text { 15-pivalate }\end{array}$ & $\begin{array}{l}\star \\
1.8(0.05) \\
25(4 \cdot 3)\end{array}$ & $\begin{array}{l}\star \\
1.2(0.03) \\
8 \cdot 3(0.58)\end{array}$ & $\begin{array}{l}\star \\
7 \cdot 7(0.41) \\
150(5 \cdot 8)\end{array}$ & $\begin{array}{l}\star \\
2 \cdot 4(0 \cdot 07) \\
74(5 \cdot 3)\end{array}$ \\
\hline $\begin{array}{r}9,11 \text {-dipivalate } \\
9,15 \text {-dipivalate } \\
\text { 11, 15-dipivalate }\end{array}$ & $\begin{array}{l}\star \\
\star \\
1.9\end{array}$ & $\begin{array}{l}\star \\
\star \\
0 \cdot 61(0 \cdot 18)\end{array}$ & $\begin{array}{l}\star \\
\star \\
12(0.98)\end{array}$ & $\begin{array}{l}\star \\
\star \\
6 \cdot 6(0 \cdot 12)\end{array}$ \\
\hline 1, 11-lactone & $1.6(0 \cdot 11)$ & $0.29(0.021)$ & $0.15(0.012)$ & $0.08 \quad(0.004)$ \\
\hline
\end{tabular}

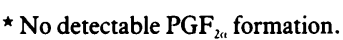

between ocular hypotension and ocular surface redness as the monoesters.

Comparison of the lactones provided more striking differences in activity. Thus, $\mathrm{PGF}_{2 a} 1$, 9-lactone was virtually devoid of ocular hypotensive activity, whereas both the 1,11 and the 1,15 lactones potently affected intraocular pressure. However, a separation of ocular hypotensive and ocular surface redness effects was apparent only for the 1, 11-lactone. $\mathrm{PGF}_{2 \mathrm{a}}$-1-isopropyl, 11pivaloyl diester was also examined as a complementary 1, 11-diester for the 1, 11-lactone internal ester. PGF $_{2 \alpha}$-1-isopropyl, 11-pivaloyl diester showed a level of activity which approximated that achieved for $\mathrm{PGF}_{2 \alpha}$ 11-pivaloyl monoester. Again, ocular hypotension tended to be maintained after ocular surface hyperaemia had resolved.

\section{Discussion}

The novel prodrug series described herein was designed to systematically evaluate the utility of esterifying the $-\mathrm{OH}$ groups on the $\mathrm{PGF}_{2 \alpha}$ molecule. Studies on their enzymatic hydrolysis, in vitro pharmacological activity and effects on the eye revealed some important considerations for the design of $\mathrm{PGF}_{2 \alpha}$ prodrugs with potential therapeutic application in glaucoma.

In studying the enzymatic conversion of these novel prodrugs to nascent $\mathrm{PGF}_{2 \alpha}$ we found that

Table 4 Rate constants ( $h /$ unit/ml) (SD) for the hydrolysis of the PGF $F_{2 a}$ prodrugs by commercial esterases

\begin{tabular}{llll}
\hline & $A C H E$ & $B u C H E$ & $C E$ \\
\hline 1-isopropyl & $\star$ & $0.027(0.001)$ & $31(0 \cdot 70)$ \\
9-pivalate & $\star$ & $\star$ & $\star$ \\
11-pivalate & $\star$ & $\star$ & $2 \cdot 5(0 \cdot 00)$ \\
15-pivalate & $\star$ & $\star$ & $1 \cdot 1(0 \cdot 13)$ \\
9, 11-dipivalate & $\star$ & $\star$ & $1 \cdot 15(0.09)$ \\
9, 15-dipivalate & $\star$ & $\star$ & $0.85(0 \cdot 20)$ \\
11, 15-dipivalate & $\star$ & $4.4(0.31)$ \\
\hline
\end{tabular}

$\star$ No detectable hydrolysis. carboxylesterase (CE) was critically important in the enzymatic hydrolysis of this novel series of $\mathrm{PGF}_{2 \mathrm{u}}$ prodrugs where the $-\mathrm{OH}$ groups had been esterified. These PGF $_{2 u}$ esters were substrates for $\mathrm{CE}$ but not ACHE or BuCHE. PGF $_{2 u}$-1-esters have previously been described as substrates for $\mathrm{BuCHE}^{20}$ and these studies confirm previous findings. However, $\mathrm{PGF}_{2 \mathrm{u}}$-1-isopropyl ester was hydrolysed at a much faster rate by $\mathrm{CE}$ indicating that $C E$ could be of greater importance in ocular enzymatic hydrolysis of this ester prodrug in the eye. The 11 and 15-monopivaloyl and the $11,15-$ dipivaloyl PGF $_{2 u}$ esters were also hydrolysed by $\mathrm{CE}$, whereas the 9-pivaloyl ester did not appear to be hydrolysed. Since $\mathrm{PGF}_{2 \mathrm{u}}$-1-isopropyl ester and the 11-mono, 15-mono, and 11, 15-diesters lowered intraocular pressure much more effectively than the $\mathrm{PGF}_{2 u}$ esters containing an acyl group at position 9, CE would appear to represent the target enzyme for designing PGF $_{2 u}$ prodrugs for treating glaucoma. CE exists, however, in several isoforms, ${ }^{2122}$ and the identity of these different CE enzymes and their regional distribution in ocular tissues remains to be determined.

The enzymatic hydrolysis rates for the $\mathrm{PGF}_{2 \alpha}$-1-isopropyl ester and the novel $\mathrm{PGF}_{2 \alpha}$ pivaloyl esters in ocular tissues varied markedly. The inability of esterases to hydrolyse acyl esters significantly at position 9 was also reflected in studies with ocular tissue homogenates; 9, 11, and 9,15-diesters were subject only to 11 and 15 hydrolysis with the 9-monoester as the final product. Although the rate constants for the 11 and 15-monopivaloyl were similar for commercially available $\mathrm{CE}, \mathrm{PGF}_{2 \alpha}$ 11-pivaloyl ester was hydrolysed approximately 10 times more slowly than $\mathrm{PGF}_{2 \alpha}$ 15-pivaloyl ester in ocular tissues. Thus, the isolated CE used for these studies does not seem to be entirely representative of esterase activity in ocular tissues. Since several isozymes of CE exist, differences in CE subtype in ocular tissues is a likely explanation for these variations in hydrolysis rate. Moreover, enzymatic hydrolysis of these $\mathrm{PGF}_{2 \alpha}$ esters by lipases cannot be discounted. Interestingly, hydrolysis of the 11ester, but not the 15-ester moiety, is strongly influenced by ester substitution at position 9 . Thus, the 11-pivaloyl group was hydrolysed much more rapidly in the case of the 9,11 diester, notably in the iris-ciliary body, whereas hydrolysis of the 15-pivaloyl group in the 9, 15diester was not similarly altered. The hydrolysis rates for the 11 and 15-monoesters were not predictive for the pattern of enzymatic conversion of $\mathrm{PGF}_{2 a} 11,15$-dipivaloyl ester. In all tissues studied, hydrolysis of the 11, 15-diester at position 11 was substantially faster than at position 15 , with no detectable levels of the 11pivalate ester in all but one ocular tissue homogenate. Thus, the order of hydrolysis for the ester groups of $\mathrm{PGF}_{2 \mathrm{u}}-11,15$-dipivalate are the converse of that which would be predicted from studies on the respective monoesters. In the case of PGF $_{2 a}$-1-isopropyl, 11-pivaloyl diester, hydrolysis of the 11-pivaloyl ester appeared rate limiting, with $\mathrm{PGF}_{2 \mathrm{f}}$ formation proceeding at a similar rate to that of the 11-monoester. $\mathrm{PGF}_{2 \alpha} 1,11$ lactone was hydrolysed more slowly. The shape and polarity changes associated with a 1, 11- 
Table 5 Comparison of the effect of $P G F_{2 a}$ esters on intraocular pressure $(\mathrm{mm} \mathrm{Hg})$ and ocular surface hyperaemia. Intraocular pressure is given as the difference between the changes from baseline in test and control eyes. Ocular surface hyperaemia is simply described as present or absent. $n=6$ or $8,{ }^{\star} p<0.05$, $\star \star_{p}<0.01$ according to Student's paired $\mathrm{t}$ test

\begin{tabular}{|c|c|c|c|c|c|c|c|c|c|c|c|c|c|c|c|}
\hline \multirow[b]{2}{*}{$P G F_{2 a}$ prodrug } & \multirow{2}{*}{$\begin{array}{l}\text { Dose } \\
\%\end{array}$} & \multicolumn{7}{|c|}{$X I O P(m m ~ H g)$ at time $(h)$ post- $P G$ administration } & \multicolumn{7}{|c|}{$\begin{array}{l}\text { \% Animals exhibiting ocular surface hyperaemia at time ( } h \text { ) } \\
\text { post-PG administration }\end{array}$} \\
\hline & & $I$ & 2 & 3 & 4 & 6 & 8 & 10 & $I$ & 2 & 3 & 4 & 6 & 8 & 10 \\
\hline $\begin{array}{l}\mathrm{GF}_{2 a} \\
\mathrm{GF}_{2 a} \\
\mathrm{GF}_{2 a}\end{array}$ & & $\begin{array}{l}+0 \cdot 4 \\
+3 \cdot 3^{\star} \\
+8 \cdot 7^{\star \star}\end{array}$ & $\begin{array}{l}-0.4 \\
-2 \cdot 4 \\
-1 \cdot 2\end{array}$ & $\begin{array}{l}-2 \cdot 33^{\star \star} \\
-6 \cdot 1^{\star \star \star} \\
-7 \cdot 2^{\star \star}\end{array}$ & $\begin{array}{l}-1 \cdot 3 \\
-3 \cdot 9^{\star} \\
-7 \cdot 0^{\star \star}\end{array}$ & $\begin{array}{l}-0 \cdot 2 \\
-2 \cdot 2^{\star \star} \\
-10 \cdot 3^{\star \star}\end{array}$ & $\begin{array}{l}- \\
-1 \cdot 1 \\
-\end{array}$ & $\begin{array}{l}\bar{z} \\
\overline{-}\end{array}$ & & $\begin{array}{l}100 \\
100 \\
100\end{array}$ & & $\begin{array}{l}50 \\
100 \\
100\end{array}$ & $\begin{array}{l}12 \cdot 5 \\
100 \\
100\end{array}$ & $\overline{75}$ & $\begin{array}{l}\bar{z} \\
=\end{array}$ \\
\hline $\mathrm{F}_{2 \mathrm{a}}-1$-isopr & & $\begin{array}{l}+6 \cdot 6^{\star \star} \\
+16 \cdot 7^{\star}\end{array}$ & $\begin{array}{l}+0.1 \\
+6.7\end{array}$ & $\begin{array}{l}-0.9 \\
-0.7\end{array}$ & $\begin{array}{l}-1 \cdot 3 \\
-3 \cdot 2^{\star}\end{array}$ & $\begin{array}{l}-5 \cdot 8^{\star \star} \\
-9 \cdot 7^{\star \star}\end{array}$ & $\begin{array}{l}-3 \cdot 4^{\star \star} \\
-10 \cdot 1^{\star \star}\end{array}$ & $\begin{array}{l}-2 \cdot 9 \star 9^{\star \star} \\
-10 \cdot 0^{\star \star}\end{array}$ & $\begin{array}{l}100 \\
100\end{array}$ & & & $\begin{array}{l}100 \\
100\end{array}$ & $\begin{array}{l}100 \\
100\end{array}$ & $\begin{array}{l}100 \\
100\end{array}$ & 100 \\
\hline & & $\begin{array}{l}+0 \cdot 1 \\
+4 \cdot 8^{\star \star} \\
+22 \cdot 9^{\star \star}\end{array}$ & $\begin{array}{l}-1 \cdot 0 \\
+5 \cdot 4^{\star \star} \\
+11 \cdot 5^{\star}\end{array}$ & $\begin{array}{l}-2 \cdot 1^{\star} \\
-0 \cdot 2 \\
+2 \cdot 1\end{array}$ & $\begin{array}{l}-1.8 \\
+0.6 \\
+6.9\end{array}$ & $\begin{array}{l}-1.7 \\
-2.5 \\
-6 \cdot 1\end{array}$ & $\begin{array}{l}-1 \cdot 8 \\
-3 \cdot 6^{\star} \\
-9 \cdot 2^{\star \star}\end{array}$ & $\begin{array}{l}- \\
-7 \cdot 4^{\star \star}\end{array}$ & & $\begin{array}{l}75 \\
100 \\
100\end{array}$ & & & $\begin{array}{l}87.5 \\
100 \\
100\end{array}$ & $\begin{array}{l}- \\
100 \\
100\end{array}$ & $\frac{-}{100}$ \\
\hline & & $\begin{array}{l}-3 \cdot 6^{\star} \\
+7 \cdot 2^{\star \star}\end{array}$ & $\begin{array}{l}-4 \cdot 1^{\star} \\
+1 \cdot 7\end{array}$ & $\overline{-}$ & & $\begin{array}{l}-1 \cdot 7 \\
-0 \cdot 6\end{array}$ & $\begin{array}{l}-1 \cdot 6 \\
-3 \cdot 0\end{array}$ & $\begin{array}{l}-1 \cdot 0 \\
-2 \cdot 1\end{array}$ & & & & & $\begin{array}{l}0 \\
100\end{array}$ & & $\begin{array}{l}0 \\
25\end{array}$ \\
\hline & & $\begin{array}{l}-1 \cdot 6 \\
+13 \cdot 5 \star \star\end{array}$ & $\begin{array}{l}-6 \cdot 9 \star \star \\
+7 \cdot 2^{\star \star}\end{array}$ & $\begin{array}{l}-7 \cdot 0^{\star \star} \\
+3 \cdot 7\end{array}$ & $\begin{array}{l}-3 \cdot 4 \\
+2 \cdot 0\end{array}$ & $\begin{array}{l}-1 \cdot 2 \\
-7 \cdot 5^{\star \star}\end{array}$ & $\overline{-}$ & $\overline{-}$ & & & & & & $\overline{-}$ & $\overline{-}$ \\
\hline & & $\begin{array}{l}-0 \cdot 7 \\
+10 \cdot 9^{\star \star} \\
+10 \cdot 0^{\star \star}\end{array}$ & $\begin{array}{l}-2 \cdot 1^{\star \star \star} \\
+4 \cdot 0^{\star \star \star} \\
+2 \cdot 9\end{array}$ & $\begin{array}{l}-0.7 \star \star \\
-0.3 \\
-1.4\end{array}$ & $\begin{array}{l}-3 \cdot 4 \\
-4 \cdot 1^{\star} \\
-3 \cdot 4^{\star}\end{array}$ & $\begin{array}{l}-1 \cdot 2 \\
-5 \cdot 3^{\star \star} \\
-11 \cdot 2^{\star \star}\end{array}$ & $\begin{array}{l}- \\
-4 \cdot 7 \star \star \\
-\end{array}$ & $\bar{z}$ & & & & & $\begin{array}{l}12 \cdot 5 \\
75 \\
100\end{array}$ & $\overline{37 \cdot 5}$ & $\overline{37}$ \\
\hline $\begin{array}{l}\text { PGF }_{2 a}^{-11-p i} \\
\text { PGF }_{2 a} \text { all-pi } \\
\text { PGF }_{2 a}-11-\text { pi }\end{array}$ & $\begin{array}{l}0.001 \\
0.01 \\
0.1 \\
1.0\end{array}$ & $\begin{array}{l}0 \\
-2 \cdot 5 \\
+12 \cdot 8^{\star} \\
+26 \cdot 3^{\star \star}\end{array}$ & $\begin{array}{l}-1 \cdot 7 \star \star \star \\
-6 \cdot 9 \star \star \\
-3 \cdot 4 \\
+13 \cdot 8^{\star \star}\end{array}$ & $\begin{array}{l}-1 \cdot 3^{\star \star} \\
= \\
-\end{array}$ & $\begin{array}{l}-1 \cdot 2 \\
-5 \cdot 1^{\star \star} \\
-10 \cdot 5^{\star \star} \\
+0 \cdot 1\end{array}$ & $\begin{array}{l}-0 \cdot 6 \\
-3 \cdot 2^{\star \star} \\
-12 \cdot 5^{\star \star} \\
-12 \cdot 2^{\star \star}\end{array}$ & $\begin{array}{l}- \\
-1 \cdot 6^{\star} \\
-10 \cdot 5^{\star \star} \\
-13 \cdot 2^{\star \star}\end{array}$ & $\begin{array}{l}- \\
-0 \cdot 5 \\
-11 \cdot 6^{\star \star} \\
-14 \cdot 3^{\star \star}\end{array}$ & $\begin{array}{l}- \\
100 \\
100 \\
33 \cdot 3\end{array}$ & $\begin{array}{l}- \\
100 \\
100 \\
33 \cdot 3\end{array}$ & $\begin{array}{l}z \\
= \\
=\end{array}$ & $\begin{array}{l}\overline{75} \\
100\end{array}$ & $\begin{array}{l}\overline{25} \\
50 \\
33 \cdot 3\end{array}$ & $\begin{array}{l}- \\
0 \\
0 \\
16.7\end{array}$ & $\begin{array}{l}- \\
0 \\
0 \\
0\end{array}$ \\
\hline $\mathrm{HF}_{2 a}-15-\mathrm{a}$ & & $\begin{array}{l}+0 \cdot 4 \\
+1 \cdot 4^{\star} \\
+3 \cdot 6^{\star \star}\end{array}$ & $\begin{array}{l}-1 \cdot 8 \\
-3 \cdot 6^{\star \star \star} \\
-0 \cdot 6\end{array}$ & $\begin{array}{l}-1 \cdot 3 \\
-3 \cdot 3^{\star \star} \\
-2 \cdot 8^{\star \star}\end{array}$ & $\begin{array}{l}-0 \cdot 7 \\
-3 \cdot 3^{\star \star} \\
-5 \cdot 4^{\star \star}\end{array}$ & $\begin{array}{l}\bar{z} \\
\overline{-}\end{array}$ & $\begin{array}{l}- \\
\overline{-}\end{array}$ & $\begin{array}{l}\bar{z} \\
\overline{-}\end{array}$ & $\begin{array}{l}- \\
-\end{array}$ & $\begin{array}{l}\overline{-} \\
\overline{-}\end{array}$ & $\begin{array}{l}- \\
-\end{array}$ & $\begin{array}{l}z \\
z\end{array}$ & $\begin{array}{l}\bar{z} \\
\overline{-}\end{array}$ & $\bar{z}$ & $\begin{array}{l}z \\
z\end{array}$ \\
\hline $\begin{array}{l}\mathrm{PGF}_{22-15-1} \\
\mathrm{PGF}_{2 a^{2}-15-1} \\
\mathrm{PGF}_{2 a}-15-1\end{array}$ & $\begin{array}{l}0 \cdot 01 \\
0 \cdot 1 \\
1 \cdot 0\end{array}$ & $\begin{array}{l}-0 \cdot 7 \\
+9 \cdot 3^{\star} \\
+18 \cdot 0^{\star \star}\end{array}$ & $\begin{array}{l}-1 \cdot 6 \\
-0 \cdot 3 \\
+8 \cdot 7 \star \star\end{array}$ & $\begin{array}{l}-5 \cdot 0^{\star \star} \\
-+3 \cdot 0^{\star \star}\end{array}$ & $\begin{array}{l}-4 \cdot 4 \star \star \\
-4 \cdot 6 \\
+2 \cdot 9\end{array}$ & $\begin{array}{l}-2 \cdot 0^{\star} \\
-8 \cdot 6^{\star \star} \\
-10^{\star \star} \cdot 7^{\star \star}\end{array}$ & $\begin{array}{l}- \\
-5 \cdot 6 \star \star \\
-\end{array}$ & $\begin{array}{l}- \\
-4 \cdot 7 \star \star \\
-\end{array}$ & $\begin{array}{l}100 \\
75 \\
100\end{array}$ & 100 & $\begin{array}{l}\frac{100}{100}\end{array}$ & & $\begin{array}{l}66 \cdot 7 \\
62 \cdot 5 \\
100\end{array}$ & $\overline{37 \cdot 5}$ & \\
\hline$P G F-15$ & & $\begin{array}{l}+2 \cdot 9^{\star} \\
+0 \cdot 2 \\
+15 \cdot 5^{\star \star}\end{array}$ & $\begin{array}{l}-1 \cdot 6 \\
-0 \cdot 3 \\
+7 \cdot 5 \star \star\end{array}$ & $\begin{array}{l}-5 \cdot 0^{\star \star} \\
+0.4\end{array}$ & $\begin{array}{l}-4 \cdot 4^{\star \star} \\
-5 \cdot 5^{\star \star} \\
-2 \cdot 9 \star\end{array}$ & $\begin{array}{l}-2 \cdot 0^{\star} \\
-8 \cdot 0^{\star \star} \\
-10^{\circ} \cdot 7^{\star \star}\end{array}$ & $\begin{array}{l}- \\
-5 \cdot 2^{\star \star} \\
-\end{array}$ & $\begin{array}{l}- \\
-3 \cdot 2 \\
-\end{array}$ & & & $\frac{100}{100}$ & & & $\overline{50}$ & \\
\hline$P G F_{2 a}-1 S-p i v$ & & $\begin{array}{l}+0 \cdot 3 \\
+8 \cdot 4^{\star \star} \\
+13 \cdot 8^{\star \star}\end{array}$ & $\begin{array}{l}-2 \cdot 8^{\star \star \star} \\
+4 \cdot 7^{\star} \\
+7 \cdot 3\end{array}$ & $\begin{array}{l}-3 \cdot 8^{\star \star} \\
=\end{array}$ & $\begin{array}{l}-1 \cdot 8 \\
-3.4 \\
-0.2\end{array}$ & $\begin{array}{l}-1 \cdot 3 \\
-4 \cdot 7 \star \star \\
-9 \cdot 3^{\star \star}\end{array}$ & $\begin{array}{l}- \\
-3 \cdot 5^{\star \star} \\
-9 \cdot 7 \star \star\end{array}$ & $\begin{array}{l}- \\
-1 \cdot 5 \\
-7 \cdot 4^{\star \star}\end{array}$ & $\overline{100}$ & $\overline{100}$ & $=$ & & $\begin{array}{l}- \\
100 \\
100\end{array}$ & $\begin{array}{l}-\overline{50} \\
100\end{array}$ & \\
\hline $\begin{array}{l}\mathrm{PGF}_{2 a}-9,11-\mathrm{c} \\
\mathrm{PGF}_{2 a}-9,11-\mathrm{c}\end{array}$ & & & $\begin{array}{l}-2 \cdot 6 \star \star \\
-2 \cdot 3\end{array}$ & $\begin{array}{l}-3 \cdot 4^{\star \star} \\
-2 \cdot 7^{\star}\end{array}$ & & $\begin{array}{l}-5 \cdot 7^{\star} \\
-3 \cdot 7^{\star}\end{array}$ & $=$ & $=$ & & & & & & $=$ & - \\
\hline $\begin{array}{l}\mathrm{PGF}_{2 a}-9,1 \\
\mathrm{PGF}_{2 a}-9,1\end{array}$ & & $\begin{array}{l}-1 \cdot 9 \star \\
-0 \cdot 2\end{array}$ & $0^{-3 \cdot 1^{\star \star}}$ & $\begin{array}{l}-3.6 \star \star \\
-0.9\end{array}$ & $0^{-1 \cdot 8^{\star}}$ & $\begin{array}{l}-0 \cdot 1 \\
-1 \cdot 5^{\star \star}\end{array}$ & $\begin{array}{l}- \\
-1 \cdot 1\end{array}$ & $\begin{array}{l}- \\
-0\end{array}$ & & & & & & $\overline{37.5}$ & $\overline{0}$ \\
\hline $\mathrm{PGF}_{2 \mathrm{a}}-9,1$ & $0 \cdot 1$ & - & $-1 \cdot 9$ & $-4 \cdot 8^{\star \star}$ & $-4 \cdot 7^{\star \star}$ & $-4 \cdot 7 \star \star$ & $-3 \cdot 3^{\star}$ & - & - & 100 & 100 & 100 & 100 & $62 \cdot 5$ & - \\
\hline $\begin{array}{l}\mathrm{PGF}_{2 a}-9, \\
\mathrm{PGF}_{2 a}-9,\end{array}$ & & $\begin{array}{l}-0.9 \\
-0.2\end{array}$ & $\begin{array}{l}-2 \cdot 3 \\
+0 \cdot 3\end{array}$ & $\begin{array}{l}-2 \cdot 5 \\
-3 \cdot 7\end{array}$ & $\begin{array}{l}-1 \cdot 5 \\
-4 \cdot 2^{\star}\end{array}$ & & & $\begin{array}{l}+3 \cdot 1 \\
-5 \cdot 2^{\star}\end{array}$ & $\begin{array}{l}62 \cdot 5 \\
87 \cdot 5\end{array}$ & $\begin{array}{l}0 \\
87 \cdot 5\end{array}$ & $\begin{array}{l}0 \\
62 \cdot 5\end{array}$ & & 50 & 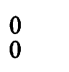 & $\begin{array}{l}0 \\
0\end{array}$ \\
\hline & & $\begin{array}{l}-2 \cdot 7^{\star \star} \\
-1 \cdot 9^{\star} \\
+5 \cdot 8^{\star}\end{array}$ & $\begin{array}{l}-2 \cdot 2^{\star \star} \\
-3 \cdot 5^{\star} \\
+1 \cdot 2\end{array}$ & $\bar{z}$ & $\begin{array}{l}-0 \cdot 3 \\
-2 \cdot 8^{\star} \\
-3 \cdot 6^{\star}\end{array}$ & $\begin{array}{l}-0 \cdot 7 \\
-1 \cdot 5^{\star} \\
-7 \cdot 2^{\star \star}\end{array}$ & $\begin{array}{l}0 \\
-1.9 \\
-7 \cdot 5^{\star \star}\end{array}$ & & $\begin{array}{l}0 \\
87 \cdot 5 \\
100\end{array}$ & & $\begin{array}{l}- \\
- \\
-\end{array}$ & & $\begin{array}{l}0 \\
87 \cdot 5 \\
100\end{array}$ & $\begin{array}{l}0 \\
12 \cdot 5 \\
100\end{array}$ & $\begin{array}{l}0 \\
0 \\
50\end{array}$ \\
\hline $\begin{array}{l}\mathrm{PGF}_{2 a^{2}}-9,1 \\
\mathrm{PGF}_{2 a}-9,1\end{array}$ & & $\begin{array}{l}-0 \cdot 7 \\
+4 \cdot 8^{\star \star}\end{array}$ & $0^{-1 \cdot 9}$ & $\overline{-}$ & $\begin{array}{l}-1 \cdot 7 \\
-2 \cdot 0\end{array}$ & & & & & & $\begin{array}{l}- \\
-\end{array}$ & & & & $\begin{array}{l}0 \\
33\end{array}$ \\
\hline & 0.01 & $\begin{array}{l}0 \\
-3.9 \star \star \\
+2.9\end{array}$ & $\begin{array}{l}0 \\
-4 \cdot 9 \star \star \\
-2 \cdot 0\end{array}$ & $\begin{array}{l}+0.5 \\
-\end{array}$ & $\begin{array}{r}-0 . \\
1 . \\
-3 .\end{array}$ & $\begin{array}{l}+0 \\
-1 \\
-3\end{array}$ & $\begin{array}{l}- \\
-1 \cdot 2 \\
-1 \cdot 7\end{array}$ & - & $\begin{array}{l}\overline{100} \\
100\end{array}$ & $\begin{array}{l}\overline{50} \\
100\end{array}$ & $\begin{array}{l}- \\
z\end{array}$ & $\begin{array}{l}-\overline{16 \cdot 7} \\
100\end{array}$ & $\begin{array}{l}\overline{0} \\
83 \cdot 3\end{array}$ & $\begin{array}{l}-\overline{0} \\
66 \cdot 6\end{array}$ & $\begin{array}{l}\overline{0} \\
16\end{array}$ \\
\hline 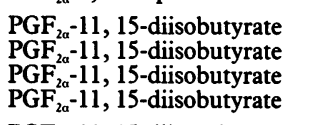 & $\begin{array}{l}0.001 \\
0 \cdot 01 \\
0 \cdot 1 \\
1 \cdot 0\end{array}$ & $\begin{array}{l}-0.6 \\
+5 \cdot 1 \\
+15 \cdot 9 \star \star \\
+26 \cdot 3^{\star \star}\end{array}$ & $\begin{array}{l}-2 \cdot 7 \\
-2 \cdot 1 \\
+2 \cdot 5 \\
+27 \cdot 2\end{array}$ & $\begin{array}{l}-1 \cdot 7 \\
-6 \cdot 9 \star \star \\
- \\
-\end{array}$ & $\begin{array}{l}-1 \cdot 3 \\
-6 \cdot 9^{\star} \\
-3 \cdot 2 \\
-\end{array}$ & $\begin{array}{l}-1 \cdot 5 \\
-4 \cdot 1^{\star \star} \\
-12 \cdot 9 \star \star \\
-11 \cdot 0^{\star \star}\end{array}$ & $\begin{array}{l}- \\
-12 \cdot 2^{\star \star} \\
-11 \cdot 4^{\star \star}\end{array}$ & $\begin{array}{l}- \\
-10 \cdot 7^{\star} \\
-14 \cdot 2^{\star \star}\end{array}$ & $\begin{array}{l}\overline{67} \cdot 5 \\
100 \\
66 \cdot 6\end{array}$ & $\overline{12.5}$ & $\begin{array}{l}\overline{0} \\
- \\
-\end{array}$ & - & $\begin{array}{l}- \\
0 \\
100 \\
100\end{array}$ & $\overline{-}$ & $\begin{array}{l}87 . \\
66 .\end{array}$ \\
\hline $\begin{array}{l}\mathrm{PGF}_{2 \mathrm{a}}-11,15 \text {-diisovalerate } \\
\mathrm{PGF}_{2 \mathrm{a}}-11,15 \text {-diisovalerate } \\
\mathrm{PGF}_{2 \mathrm{a}}-11,15 \text {-diisovalerate }\end{array}$ & $\begin{array}{l}0 \cdot 001 \\
0 \cdot 01 \\
0 \cdot 1\end{array}$ & $\begin{array}{l}-1 \cdot 0^{\star \star} \\
+6 \cdot 5^{\star \star} \\
+24 \cdot 9^{\star \star}\end{array}$ & $\begin{array}{l}-1 \cdot 2 \\
+0 \cdot 6 \\
+13 \cdot 7 \star \star\end{array}$ & $\begin{array}{l}-1 \cdot 0 \\
-\end{array}$ & $\begin{array}{l}-1 \cdot 5 \\
-2 \cdot 6 \\
-1 \cdot 2\end{array}$ & & $\begin{array}{l}- \\
-3 \cdot 6^{\star \star} \\
-12 \cdot 0^{\star \star}\end{array}$ & $\begin{array}{l}- \\
-3 \cdot 1^{\star \star} \\
-13 \cdot 0^{\star \star}\end{array}$ & $\begin{array}{l}-\overline{100} \\
50\end{array}$ & $\begin{array}{l}- \\
100 \\
33 \cdot 3\end{array}$ & $\begin{array}{l}\overline{-} \\
\overline{-}\end{array}$ & $\begin{array}{l}- \\
66 \cdot 6\end{array}$ & $\overline{100}$ & $\begin{array}{l}\overline{75} \\
0\end{array}$ & 0 \\
\hline $\begin{array}{l}\mathrm{PGF}_{2 a}-11,15 \text {-dipivalate } \\
\text { PGF }_{2 a}-11,15 \text {-dipivalate }\end{array}$ & 0.01 & $\begin{array}{l}+9 \cdot 2 \\
+14 \cdot 7 \star \star\end{array}$ & $\begin{array}{l}+4 \cdot 8^{\star \star} \\
+8 \cdot 8^{\star \star}\end{array}$ & $\begin{array}{l}-0 \cdot 5 \\
+5 \cdot 2\end{array}$ & $\begin{array}{l}-1 \cdot 8 \\
+1 \cdot 1\end{array}$ & & $\begin{array}{l}-6 \cdot 9^{\star \star} \\
-10 \cdot 5^{\star \star}\end{array}$ & $\begin{array}{l}-5 \cdot 0^{\star \star} \\
-10 \cdot 0^{\star \star}\end{array}$ & & & & & & $\begin{array}{l}37 \cdot 5 \\
100\end{array}$ & \\
\hline 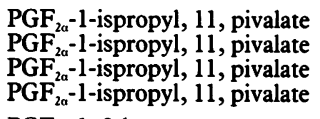 & $\begin{array}{l}0 \cdot 001 \\
0 \cdot 01 \\
0 \cdot 1 \\
1 \cdot 0\end{array}$ & $\begin{array}{l}+1 \cdot 7 \\
-4 \cdot 1^{\star} \\
+6 \cdot 8 \\
+6 \cdot 8^{\star \star}\end{array}$ & $\begin{array}{l}0 \\
-6.9 \star \star \\
+3.5 \\
-1.5 \star\end{array}$ & $\begin{array}{l}-0 \cdot 7 \\
-5 \cdot 4^{\star \star} \\
-\end{array}$ & $\begin{array}{l}0 \\
-3 \cdot 6^{\star \star} \\
-1 \cdot 7 \\
-8 \cdot 0^{\star \star}\end{array}$ & $\begin{array}{l}-0 \cdot 3 \\
-2 \cdot 7^{\star \star} \\
-5 \cdot 0^{\star \star} \\
-10 \cdot 6^{\star \star}\end{array}$ & $\begin{array}{l}- \\
- \\
-6 \cdot 7 \star \star \\
-7 \cdot 5 \star \star\end{array}$ & $\begin{array}{l}- \\
-4 \cdot 3^{\star \star} \\
-7 \cdot 2^{\star \star}\end{array}$ & $\begin{array}{l}- \\
100 \\
100 \\
100\end{array}$ & $\begin{array}{l}- \\
100 \\
100 \\
100\end{array}$ & $\begin{array}{l}\overline{100} \\
- \\
-\end{array}$ & - & $\begin{array}{l}- \\
50 \\
50 \\
100\end{array}$ & $\begin{array}{l}- \\
\overline{12} \cdot 5 \\
100\end{array}$ & 50 \\
\hline & & $\begin{array}{l}-0.8 \\
-0.1 \\
-1 \cdot 7^{\star}\end{array}$ & $\begin{array}{l}-0 \cdot 5 \\
-0 \cdot 8 \\
-2 \cdot 7^{\star \star}\end{array}$ & +0.9 & -0.7 & $\begin{array}{l}-0.6 \\
-0.6 \\
+0.5\end{array}$ & $\begin{array}{l}- \\
z\end{array}$ & $\begin{array}{l}\bar{z} \\
\overline{-}\end{array}$ & & $\begin{array}{l}- \\
\overline{-}\end{array}$ & $\bar{z}$ & $\begin{array}{l}- \\
z\end{array}$ & $\begin{array}{l}0 \\
0 \\
25\end{array}$ & $\begin{array}{l}- \\
-\end{array}$ & - \\
\hline $\begin{array}{l}\mathrm{PGF}_{2 \mathrm{a}}-1,11-\mathrm{la} \\
\mathrm{PGF}_{2}-1,11-\mathrm{la}\end{array}$ & $\begin{array}{l}0 \cdot 01 \\
0 \cdot 1 \\
1 \cdot 0\end{array}$ & $\begin{array}{l}0 \\
+3 \cdot 3^{\star} \\
+6 \cdot 0^{\star \star}\end{array}$ & $\begin{array}{l}-0.5 \\
+1.2 \\
+0.5\end{array}$ & $\begin{array}{l}+0 \cdot 9 \\
-6 \cdot 3 \star \star \\
-1 \cdot 0\end{array}$ & & & $\begin{array}{l}- \\
-4 \cdot 0 \\
-\end{array}$ & $\begin{array}{l}- \\
-4 \cdot 0 \\
-\end{array}$ & 50 & $\begin{array}{l}- \\
-\end{array}$ & $\overline{100}$ & $\frac{-}{100}$ & $\begin{array}{l}0 \\
75 \\
75\end{array}$ & $\overline{62 \cdot 5}$ & \\
\hline $\begin{array}{l}\mathbf{P G F}_{2 \mathrm{an}}-1,15 \text {-lactone } \\
\mathrm{PGF}_{2 \mathrm{a}}-1,15 \text {-lactone } \\
\text { PGF }_{2 \mathrm{a}}-1,15 \text {-lactone }\end{array}$ & $\begin{array}{l}0 \cdot 01 \\
0 \cdot 1 \\
1 \cdot 0\end{array}$ & $\begin{array}{l}-1 \cdot 1 \\
+0 \cdot 1 \\
+2 \cdot 4\end{array}$ & $\begin{array}{l}-2 \cdot 6^{\star} \\
-3 \cdot 2^{\star \star} \\
-2 \cdot 6\end{array}$ & $\begin{array}{l}-3 \cdot 0^{\star \star} \\
-4 \cdot 8^{\star \star} \\
-6 \cdot 8^{\star \star}\end{array}$ & $-7 \cdot 0^{\star \star}$ & $\begin{array}{l}0 \\
-4 \cdot 5^{\star \star} \\
-8 \cdot 9^{\star \star}\end{array}$ & $\begin{array}{l}- \\
-\end{array}$ & $\begin{array}{l}- \\
-\end{array}$ & & $\begin{array}{l}\overline{-} \\
\bar{z}\end{array}$ & $\begin{array}{l}- \\
-\end{array}$ & $\begin{array}{l}- \\
-\end{array}$ & $\begin{array}{l}0 \\
75 \\
100\end{array}$ & $\begin{array}{l}z \\
z\end{array}$ & $\begin{array}{l}z \\
z\end{array}$ \\
\hline
\end{tabular}

lactone (internal ester) may influence its ability to act as a substrate for many enzymes. ${ }^{12}$

The ultimate objective in designing PGF $_{2 u}$ prodrugs is to design agents which lower intraocular pressure with minimal ocular surface hyperaemia. In order to accomplish this objective, enzymatic hydrolysis must be minimised in the conjunctiva and also in the corneal epithelium so as to avoid back diffusion of nascent $\mathrm{PGF}_{2 \mathrm{u}}$ to the tear film. The ratio of formation rate between the iris-ciliary body and the ocular surface tissues would be expected to be large for a prodrug with clinical potential. This is not the case for $\mathrm{PGF}_{2 \mathrm{u}}$-1-isopropyl ester where combined $\mathrm{PGF}_{2 \mathrm{u}}$ formation for the corneal epithelium and the conjunctiva clearly exceeds that of the irisciliary body. For the 11-mono, 15-mono, and 11, 15-diesters, the conversion rate in the iris-ciliary body exceeded that in the ocular surface tissues. Since the uveoscleral site of action of $\mathrm{PGF}_{24}{ }^{23}$ 
resides in the vicinity of the ciliary body, these novel agents appear to provide a step towards identifying a $\mathrm{PGF}_{2 u}$ prodrug with clinical utility.

In addition to a favourable enzymatic conversion profile, inherent pharmacological activity of a prodrug should be minimal. In order to determine inherent pharmacological activity, intracellular $\left[\mathrm{Ca}^{2+}\right]$ in Swiss 3T3 cells was used as a cell pharmacology model for the FP receptor..$^{13}$ This is a useful system for identifying inherent $\mathrm{PGF}_{2 \alpha}$ prodrug activity from a number of standpoints. In particular, the $\mathrm{Ca}^{2+}$ signal is rapid response which minimises the potential influence of intracellular CE activity. The structure-activity profile for the $\mathrm{PGF}_{2 \mathrm{u}}$ prodrugs may be summarised as follows. Firstly, a - $\mathrm{COO}^{-}$group appears critical for FP receptor stimulation: removal of the formal negative charge by esterification or lactonisation results in compounds which are essentially devoid of activity. Secondly, monoesterification of the - $\mathrm{OH}$ groups can provide compounds which retain approximately 100th of the activity of $\mathrm{PGF}_{2 \alpha}$ regardless of the position of the ester group. Diesterification is required for compounds with reduced potency at the FPreceptor comparable with that of $\mathrm{PGF}_{2 \mathrm{u}}-1$ isopropyl ester. The size of the acyl ester also appears important. In the case of monoesters, $\mathrm{PGF}_{2 u}-9$-acetate was approximately 10 times more potent than $\mathrm{PGF}_{2 \alpha}$-9-isobutyrate or 9-pivalate. This may not hold for the diesters since all the 9, 11-diesters were approximately equiactive.

In terms of obtaining separation between ocular hypotensive and ocular surface hyperaemic effects, the objective was partially achieved with the 11 and 15-monoesters, and the 11, 15-diesters. The separation was temporal and most apparent at later time points. The ocular hypotensive activity of the 11 and 15-monoesters and the 11,15-diesters was comparable with that of $\mathrm{PGF}_{2 u}$-1-isopropyl ester, despite being converted to $\mathrm{PGF}_{2 \mathrm{u}}$ at a much slower rate in the irisciliary body. This suggests that rapid formation of nascent $\mathrm{PGF}_{2 \mathrm{u}}$ is not necessary for providing an acceptable level of ocular hypotensive activity. The ocular hypotensive activity of $\mathrm{PGF}_{2 u} 1,11$ lactone lends further support to this view. The lactone series exhibited a rank order of potency $[1,15>11,11>1,9$ - (inactive) $]$, which is essentially consistent with hydrolysis rates in previously investigated biological systems. ${ }^{12}$

In addition to ocular hypotension, an initial ocular hypertensive response was also observed for most of the PGF $_{2 u}$ esters. This phenomenon has been extensively reported as prominent in rabbits and results from breakdown of the bloodaqueous barrier. ${ }^{24-26}$ Such responses to $\mathrm{PGF}_{2 a}$, its esters, and its structural analogues are minimal or absent in cats, dogs, monkeys, and human subjects. $^{1-9}$ Thus, the ocular hypertensive responses observed in rabbits have little or no clinical significance.

Despite the absence of measurable enzymatic hydrolysis, $\mathrm{PGF}_{2 \alpha}$ 9-mono, 9, 11, and 9, 15diesters did exhibit ocular hypotensive activity, albeit much weaker than the other esters evaluated. Moreover, some ocular surface hyperaemia was apparent. The detection limit of the ester hydrolysis assay is approximately $0.3 \mathrm{nM} / \mathrm{ml}$ and the formation of a small, undetectable level of nascent $\mathrm{PGF}_{2 u}$ may account for the activity observed for 9-mono and 9-diesters. Regardless of these modest activities, emphasis on 11 and 15esters appears preferable for the design of PGF $_{2 a}$ prodrugs with potential clinical application.

The authors express their appreciation to $\mathrm{J}$ Boag for excellent secretarial assistance and to Dr D S Chien for helpful critique. They also thank Dr Gordon L Bundy of Upjohn for providing samples of the $\mathrm{PGF}_{2 \mathrm{t}}$ lactones used in these studies.

1 Bito LZ, Drago A, Blanco J, Camras CB. Long-term maintenance of reduced intraocular pressure by daily or twice daily topical application of prostaglandins to cat and rhesus monkey eyes. Invest Ophthalmol Vis Sci1983; 24: 312-9.

2 Lee P-Y, Podos SM, Severin C. Effect of prostaglandin $F_{24}$ on aqueous humor dynamics of rabbit, cat, and monkey. Invest Ophthalmol Vis Sci 1984; 25: 1087-93.

3 Bito LZ. Comparison of the ocular hypotensive efficacy of eicosanoids and related compounds. Exp Eye Res 1984; 38 : 181-94.

4 Woodward DF, Burke JA, Williams LS, Palmer BP, Wheeler LA, Woldemussie E, et al. Prostaglandin $\mathrm{F}_{2 a}$ effects on intraocular pressure negatively correlate with FP-receptor stimulation. Invest Ophthalmol Vis Sci 1989; 36: 1838-42.

Gluffré $G$. The effects of prostaglandin $F_{2,4}$ in the human eye Graefes Arch Clin Exp Ophthalmol 1985; 222: 139-41.

6 Lee P-Y, Shao H, Xu L, Qu C-K. The effect of prostaglandin $\mathrm{F}_{2 u}$ on intraocular pressure in normotensive human subjects. Invest Ophhthalmol Vis Sci 1988; 29: 1474-77.

7 Kerstetter MS, Brubaker RF, Wilson SE, Kullerstrand LJ. Prostaglandin-1-isopropylester lowers intraocular pressure Prostaglandin-1-isopropylester lowers intraocular pressure
without decreasing aqueous humor flow. Am $\mathcal{F}$ Ophthalmol without decreasing

8 Villumsen J, Alm A. Prostaglandin $\mathrm{F}_{2 \mathrm{a}}$-isopropyl eye drops: effects in normal human eyes. $\mathrm{Br} \mathrm{f}^{20}$ Ophthalmol 1989; 73: 419-26.

9 Camras CB, Siebold EC, Lustgarten JS, Serle JB, Frisch SC, Podos SM, et al. Maintained reduction of intraocular pressure by prostaglandin $F_{21}-1$-isopropyl ester applied in multiple doses in ocular hypertensive and glaucoma patients. Ophthalmology 1989; 96: 1329-37.

10 Bito LZ, Baroody RA. The ocular pharmacokinetics of eicosanoids and their derivatives. 1. Comparison of ocular eicosanoid penetration and distribution following the topical application of $\mathrm{PGF}_{24}, \mathrm{PGF}_{24}-1$-methyl ester, and $\mathrm{PGF}_{24}-1-$ application of $\mathrm{PGF}_{2 u}, \mathrm{PGF}_{2 \mathrm{iu}}-1$-methyl ester,
isopropyl ester. ExpEye Res 1987; 44: 217-26.

11 Morozowich W, Oesterling TO. Miller WL, Lawson CF, Cornette JC, Weeks JR, et al. Prostaglandin prodrugs. III: Synthesis and biological properties of $\mathrm{C}_{9}-$ and $\mathrm{C}_{15}$ monoesters of dinoprost (prostaglandin $\mathrm{F}_{2 \mathrm{a}}$ ). $\mathcal{F}^{\mathrm{P}}$ harm $\mathrm{Sc}_{\mathrm{s}}$ 1979; 68: 949-51

12 Bundy GL, Peterson DC, Carnette JC, Miller WL, Spilman $\mathrm{CH}$, Wilks JW. Synthesis and biological activity of prostaglandin lactones. F Med Chem 1983; 26: ${ }^{-1089-99}$

13 Woodward DF, Fairbairn CE, Goodrum DD, Krauss A H-P, Ralston TL, Williams LS. C ${ }^{2+}$ transients evoked by prostanoids in Swiss 3T3 cells suggest an FP-receptor mediated noids in Swiss 3 T3 cells suggest an FP-receptor mediated G, Granstrom E, eds, Advances in prostaglandin, thromboxane, and leukotriene research. New York: Raven Press, 1990: 21: $367-70$.

14 Yamaguchi DT, Hahn TJ, Beeker TG, Kleeman CR, Maullem $S$. Relationship of cAMP and calcium messenger systems in prostaglandin stimulated UMR-106 cells. F Biol Chem 1988; 263: 10745-53.

15 Chan MF, Woodward DF. Intraocular pressure reducing 11acyl prostaglandins. Eur patent 0308268, 1990.

16 Chan MF, Gluchowski C, Woodward DF. Intraocular pressure reducing 9, 11-diacyl prostaglandins. US patent 5034413,1991 .

17 Chan MF, Woodward DF. Intraocular pressure reducing 9 , 15-diacyl prostaglandins. US patent 5028624, 1991 .

18 Chan MF, Woodward DF. Intraocular pressure reducing 11 , 15-diacyl prostaglandins. US patent 4994274, 1991

19 Chan MF, Woodward DF, Gluchowski C. Intraocular pressure reducing 15-acyl prostaglandins. Eur patent 0399839 , 1990.

20 Camber O, Edman P. Factors influencing the corneal permeability of prostaglandin $\mathrm{F}_{2 \mathrm{x}}$ and its isopropyl ester in vitro. Int f Pharm 1987; 37: 27-32.

21 Chemritus JM, Zech R. Carboxylesterases in primate brain: characterization of multiple forms. Int $\mathcal{F}$ Biochem 1983; 15: 1019.

22 Mentlein R, Schumann M, Heymann E. Comparative chemical and immunological characterization of five lipolytic enzymes (carboxylesterases) from rat liver microsomes. Arch Biochem Biophys 1984; 234: 612-21.

23 Crawford K, Kaufman PL, Gabelt BT. Effects of topical prostaglandin $\mathrm{F}_{2 \mathrm{u}}$ on aqueous humor dynamics in cynomolgus monkeys. Curr Eye Res 1987; 6: 1035-44.

24 Bito LZ. Species differences in the response of the eye to irritation and trauma: a hypothesis of divergence in ocular defense mechanisms, and the choice of experimental animals for eye research. Exp Eye Res 1984; 39: 807-29.

25 Neufeld AH, Sears ML. Prostaglandin and eye. Prostaglandins 1973; 4: 157-75.

26 Protzman CE, Woodward DF. Prostanoid-induced bloodaqueous barrier breakdown in rabbits involves the EP2 receptor subtype. Invest Ophthalmol Vis Sci 1990; 31: 2463-6. 